\title{
Pengaruh Sekolah Inklusi terhadap Kepekaan Sosial Siswa Sekolah Dasar
}

\author{
The Influences of Inclusive School on Social Sensitivity \\ of Elementary School Student
}

\author{
Tarindra Puspa Wijayanti, Wiwi Afita \& Grehas Wilantanti \\ Universitas Negeri Semarang, Semarang, Jawa Tengah, Indonesia \\ tarindrapuspa@gmail.com
}

Naskah diterima tanggal 30/06/2019, direvisi akhir tanggal 22/07/2019, disetujui tanggal 31/07/2019

\begin{abstract}
Abstrak
Kepekaan sosial adalah kemampuan seseorang untuk bereaksi secara cepat dan tepat terhadap objek atau situasi sosial tertentu yang ada di sekitarnya. Lingkungan sekitar anak akan sangat mempengaruhi kepekaan sosial anak. Sekolah inklusi adalah salah satu sarana untuk meningkatkan kepekaan sosial anak karena di dalamnya terdapat anak berkebutuhan khusus yang dapat melatih kepedulian terhadap sesama. Penelitian yang telah dilakukan bertujuan untuk menganalisis dan mendeskripsikan pengaruh sekolah inklusi terhadap kepekaan sosial anak SD Slerok 2 Kota Tegal. Metode penelitian yang digunakan dalam penelitian ini adalah metode deskriptif kuantitatif. Populasi dan sampel penelitian adalah siswa ATBK (anak tanpa berkebutuhan khusus) kelas III, IV, V, dan VI SD Slerok 2 Kota Tegal yang berjumlah 117 siswa. Teknik pengambilan sampel yang digunakan adalah teknik jenis sampling jenuh. Teknik pengumpulan data dilakukan dengan: 1) Wawancara; 2) Angket; dan 3) Dokumentasi. Metode analisis data terdiri dari: analisis deskriptif, uji prasyarat, dan analisis regresi linear sederhana. Hasil penelitian menunjukan bahwa sekolah inklusi berpengaruh positif dan signifikan terhadap kepekaan sosial anak sebesar 37,5\%, sedangkan sisanya 73,5\% dipengaruhi oleh faktor lain yang tidak diteliti dalam penelitian ini. Hasil penelitian diperoleh $t_{\text {hitung }}>t_{\text {tabel }}(8,087>1,982)$ dan korelasi keduanya sebesar 0,612, yaitu dalam kategori kuat.
\end{abstract}

Kata kunci: ATBK, ABK, Kepekaan Sosial, Sekolah Inklusi.

\section{Abstract}

Social sensitivity is the ability of a person to react quickly and precisely to certain objects or social situations around him. The environment around children will greatly affect the social sensitivity of children. Inclusion schools are one of the means to improve children's social sensitivity because in them, there are children with special needs who can train to care for others. This research aims to analyze and describe the influence of inclusive schools on children's social sensitivity in SD Slerok 2 Kota Tegal. The research method used in this research is a quantitative descriptive method. The population and sample of this study are normal students (nondisabled)class III, IV, V, and VI to SD Slerok 2 Kota Tegal amounting to 117 students. The sampling technique used is saturated sampling technique. Data collection techniques used are: 1) interviews;2) Questionnaire; and 3)Documentation. The data analysis method used descriptive analysis, prerequisite analysis, and final analysis. The results of the study indicate that inclusive schools have a positive and significant effect on children 's social sensitivity by $37,5 \%$. The result of the study obtained $t_{\text {count }}>t_{\text {table }}(8,087>1,982)$ and the correlation between them wa 0,612, which is in the strong category.

Keyword: Children With Disability, Normal Students, Inclusive School, Social Sensitivity. 


\section{PENDAHULUAN}

Pendidikan inklusi merupakan salah satu bentuk penyelenggaraan pendidikan yang memberikan kesempatan kepada semua peserta didik dengan segala potensi dan kelainannya. Penyelenggaraan sistem sekolah inklusi merupakan salah satu syarat yang harus terpenuhi untuk membangun masyarakat inklusi. Sebuah tatanan masyarakat yang saling menghormati dan menjunjung tinggi nilai-nilai keberagaman sebagai realitas kehidupan. Banyak kasus yang muncul terkait pelaksanaan pendidikan inklusi, seperti minimnya sarana penunjang sistem pendidikan inklusi, terbatasnya pengetahuan, dan keterampilan yang dimiliki oleh para guru sekolah inklusi, menunjukkan bahwa sistem pendidikan inklusi belum dipersiapkan dengan baik. Penyelenggaraan sekolah inklusi bagi anak berkebutuhan khusus seharusnya menciptakan lingkungan yang ramah terhadap pembelajaran, yang memungkinkan semua siswa dapat belajar dengan nyaman dan menyenangkan. Penyelenggaraan sekolah inklusi memang tidak sesederhana menyelenggarakan sekolah umum. Kenyataan di lapangan dalam hal karakteristik anak berkebutuhan khusus yang diterima belum sesuai dengan kebijakan, seperti dalam hal penerimaan jenis kekhususan, tingkat kecerdasan yang masih dibawah rata, belum ada penentuan batas jumlah siswa yang diterima, serta belum memiliki sarana prasaranan khusus. Dukungan dari orangtua anak berkebutuhan khusus, orangtua siswa regular, maupun masyarakat baru berupa dukungan moral.

Istilah pendidikan inklusi berawal dari pernyataan UNESCO yaitu Education for All yang artinya pendidikan yang ramah untuk semua, dengan pendekatan yang berusaha menjangkau semua orang. Implementasi pendidikan inklusi didasari oleh dokumendokumen internasional, yaitu Deklarasi Universal Hak Asasi Manusia tahun 1948, Konvensi PBB tentang Hak Anak tahun 1989. Berdasarkan undang-undang nomor 70 tahun 2009 pasal 1 menjelaskan bahwa pendidikan inklusif adalah sistem penyelenggaraan pendidikan yang memberikan kesempatan kepada semua peserta didik yang memiliki kelainan dan memiliki potensi kecerdasan dan/atau bakat istimewa untuk mengikuti pendidikan atau pembelajaran dalam satu lingkungan pendidikan secara bersamasama dengan peserta didik pada umumnya. Pendidikan inklusi tidak hanya diterapkan untuk anak-anak berkebutuhan khusus melainkan untuk semua baik siswa yang memilikikelainan, potensiatau bakatistimewa maupun bagi peserta didik yang normal karena pada dasarnya semua anak memiliki hak yang sama. Pendidikan inklusi adalah sebuah paradigma yang humanis dan falsafah pendidikan yang dapat mengakomodasi semua peserta didik sesuai dengan kebutuhannya, selain itu pendidikan inklusi adalah pendidikan yang tidak diskriminatif yang memberikan layanan terhadap semua peserta didik tanpa memandang kondisi fisik, mental, intelektual, sosial emosi, ekonomi, jenis kelamin, suku, budaya tempat tinggal, bahasa, dan sebagainya (Kustawan, 2013: 1213). Dalam penyelenggaraan sekolah inklusi terdapat indeks yang dapat mengevaluasi pelaksanaan sekolah inklusi. Booth and Ainscow (2002) mengembangkan index for inclusif, diantaranya adalah: (1) dimensi Budaya (creating inclusive cultures), (2) dimensi Kebijakan (producing inclusive policies), dan (3) dimensi praktek (evolving inclusive practices).

Pelaksanaan pendidikan dilapangan cenderung menilai bahwa jika anak berkebutuhan khusus diberikan pelayanan pendidikan yang sama dan bersamaan dengan anak normal maka hanya akan mengganggu proses pendidikan pada anak normal. Konsep pendidikan seperti ini akan membawa dampak pada anak berkebutuhan khusus maupun normal, yaitu apatis, tidak percaya diri, individualisme, dan tidak siap hidup dengan masyarakat (Dewi, 2017: 13). Pengabaian terhadap norma, kurang berartinya nilai-nilai atau norma-norma yang berlaku dalam suatu kelompok sosial masyarakat dapat berpengaruh terhadap kepekaan sosial. Kepekaan sosial merupakan kemampuan untuk berinteraksi dan tanggap terhadap lingkungan di sekitarnya. (Thomas 
Lickona, 2008: 53) dalam Rohima (2018:

9) terdapat beragam kepekaan sosial antara lain bersedia membantu orang yang membutuhkan, berbagi dengan orang lain, menghargai orang lain yang memiliki kondisi berbeda.

Banyak anak enggan atau jarang melakukan komunikasi dengan anakanak yang berkebutuhan khusus. Anakanak yang normal cenderung tidak begitu mempedulikan keberadaan anak-anak yang berkebutuhan khusus bahkan ada beberapa anak yang menganggap bahwa keberadaan anak berkebutuhan khusus tersebut justru menggangu. Dampak bagi anak-anak berkebutuhan khusus sendiri akan mengakibatkan suatu ketidakmampuan sosial. Ketidakmampuan sosial ini adalah ketidakmampuan untuk memahami aturan sosial dalam keluarga sekolah, dan masyarakat. Dalam interaksi sosial ini terdapat kebutuhan sosial yang penting bagi anak berkebutuhan khusus. Kebutuhan sosial ini mengarah langsung pada pentingnya daya dorong interaksi sosial yang positif di antara anak berkebutuhan khusus dengan temantemannya yang tidak terhambat (nondisabled) (Smith, 2017: 123).

Fenomena-fenomena tersebut menunjukkan kebutuhan lingkungan inklusif bagi anak menjadi penting. Keberadaan sekolah inklusi akan memberikan dampak tersendiri bagi pengembangan kepribadian dan kepekaan sosial anak. Terdapat berbagai faktor yang menyebabkan anak normal kurang memiliki kepekaan kepada anak yang berkebutuhan khusus. Disini seorang guru dan lingkungan sekolah sangat berperan dalam mengasah kepekaan sosial anak, karena sejatinya manusia merupakan makhluk sosial yang memerlukan komunikasi dengan makhluk lainnya. Darley dan Latene (Sarwono dan Meinarno, 2009) mengemukakan beberapa faktor yang dapat berpengaruh terhadap kepekaan sosial, diantaranya :

1. Bystander. Bystander adalah orangorang yang berada di sekitar tempat kejadian mempunyai peran sangat besar dalam mempengaruhi seseorang saat memutuskan antara menolong atau tidak ketika dihadapkan pada keadaan darurat.

2. Atribusi. Seseorang akan termotivasi untuk memberikan bantuan orang lain bila ia mengasumsikan bahwa ketidakberuntungan korban adalah diluar kendali korban. Oleh karena itu seseorang akan lebih bersedia memberikan sumbangan kepada pengemis yang cacat dan tua dibandingkan dengan pengemis yang masih mudah.

3. Model. Orang-orang kemungkinan akan lebih besar untuk memberikan sumbangannya di kotak amal yang disediakan ditoko bila sebelumnya mereka melihat orang lain juga menyumbang.

4. Sifat dan Suasana hati (mood). Orang yang mempunyai sifat pemaaf akan mempunyai kecenderungan mudah menolong.

Selain faktor tersebut terdapat faktor lain yaitu faktor-faktor yang dapat mempengaruhi perilaku seseorang adalah faktor genetik, meliputi: jenis ras, jenis kelamin, sifat fisik, sifat kepribadian, bakat pembawaan dan inteligensi. Selanjutnya adalah faktor dari luar individu: faktor lingkungan, pendidikan, agama, sosial ekonomi, kebudayaan dan faktor-faktor lain.

SD Slerok 2 merupakan salah satu sekolah dasar di kota Tegal yang menjalankan program sekolah inklusi. Keberadaan anakanak berkebutuhan khusus di SD Slerok 2 menjadikan anak-anak tanpa berkebutuhan khusus (ATBK) harus dapat memahami bahwa teman mereka ada yang berbeda dan memerlukan perlakuan khusus. Guru dan siswa ATBK harus dapat mendukung untuk menciptakan lingkungan yang inklusif bagi anak-anak berkebutuhan khusus sehingga anak-anak berkebutuhan khusus merasakan lingkungan yang ramah dan nyaman. Di sini kepekaan sosial ATBK terhadap anakanak berkebutuhan akan diuji dan dapat berkembang.

Jenis anak berkebutuhan khusus di SDN Slerok 2 Kota Tegal terdiri dari autis ringan dan lamban belajar. Fokus penelitian yaitu siswa ATBK kelas III, IV, dan V. Siswa kelas III berjumlah 31 anak yang terdiri dari 
3 ABK dan 28 ATBK, kelas IV berjumlah 29 ATBK, kelas V berjumlah 32 yang terdiri dari 1 ATBK dan 31 ABK, serta kelas VI yang berjumlah 31 siswa terdiri dari 2 ABK dan 29 ATBK. Siswa ATBK menyadari bahwa mereka bersekolah di sekolah inklusi yang siswanya beragam dan mereka menyadari bahwa teman mereka berkebutuhan khusus. Siswa ATBK cenderung memahami keaadaan temannya. Mereka memaklumi perilaku temannya berbeda dan terkadang mengganggu siswa ATBK. Melihat teman yang seperti itu siswa ATBK memiliki kecenderungan untuk berusaha peduli dan membantu meskipun terkadang juga mereka merasa terganggu dengan Siswa ABK.

Rumusan masalah dalam penelitian ini adalah bagaimana pengaruh sekolah inklusi terhadap kepekaan sosial anak SD Slerok 2 Kota Tegal?. Berdasarkan rumusan masalah tersebut, tujuan dari penelitian ini adalah mengetahui pengaruh sekolah inklusi terhadap kepekaan sosial anak SD Slerok 2 Kota Tegal.

\section{METODE PENELITIAN}

Penelitian ini menggunakan metode penelitian kuantitatif jenis deskriptif kuantitatif. Metode deskriptif kuantitatif adalah metode penelitian yang mendeskripsikan variabel- variabel yang diteliti tanpa memanipulasi variabel-variabel tersebut. Penelitian ini dilaksanakan selama 2 bulan. Adapun penelitian ini dilaksanakan di SD Slerok 2 Kota Tegal. Pemilihan SD Slerok 2 didasarkan padakenyataan bahwa SD Slerok 2 merupakan sekolah dasar di kecamatan Tegal barat kota tegal yang masih melaksanakan program inklusi. Di kecamatan tegal barat terdapat 4 SD yang diamanatkan sebagai sekolah inklusi. Namun SD Slerok 2 merupakan satusatunya SD yang masih menjalankan program inklusi. Sedangkan sekolah lainnya sudah tidak menjalankan program inklusi lagi. Hal ini karena dana penyelenggaraan sekolah inklusi dari pemerintah sudah tidak turun lagi dan tidak adanya guru pendamping khusus (GPK) membuat sekolah lain melepaskan status sekolah inklusinya. Populasi dalam penelitian ini adalah siswa ATBK yang berjumlah 117 siswa yang terdiri dari kelas III, IV, V, dan VI. Adapun populasi kelas III terdiri dari 28 siswa, kelas IV terdiri 29 siswa, kelas V terdiri dari 31 siswa, kelas VI terdiri dari 29 siswa. Teknik pengambilan sampel menggunakan teknik sampling jenuh yaitu semua populasi dijadikan sebagai sampel penelitian sehingga jumlah sampel sebanyak 117 siswa. Dengan rincian sebagai berikut:

Tabel 1. Data siswa SD Slerok 2 Kota Tegal

\begin{tabular}{ccccc}
\hline \multirow{2}{*}{ No } & \multirow{2}{*}{ Kelas } & \multicolumn{2}{c}{ Jenis kelamin } & \multirow{2}{*}{ Jumlah } \\
\cline { 3 - 4 } & & $\mathbf{L}$ & $\mathbf{P}$ & \\
\hline 1 & Kelas III & 15 & 13 & 28 \\
\hline 2 & Kelas IV & 13 & 16 & 29 \\
\hline 3 & Kelas V & 18 & 13 & 31 \\
\hline 4 & Kelas VI & 11 & 18 & 29 \\
\hline Jumlah & $\mathbf{5 5}$ & $\mathbf{6 2}$ & $\mathbf{1 1 7}$ \\
\hline
\end{tabular}

(Data wali kelas SD Slerok 2 Kota Tegal)

Teknik pengumpulan data dilakukan dengan: 1) wawancara, 2) Angket, 3) Dokumentasi. Wawancara dalam penelitian ini dilakukan untuk mendapatkan informasi awal mengenai permasalahan dan gambaran umum yang terjadi di lokasi penelitian. Penelitian ini menggunakan angket atau kuesioner tertutup. Kuesioner tertutup merupakan kuesioner yang jawabannya yang sudah tersedia sehingga responden tinggal memilih. Angket ini digunakan untuk mengetahui variabel sekolah inklusi dan kepekaan sosial. Dokumentasi dalam penelitian ini digunakan untuk memeroleh data berkaitan dengan jumlah siswa ATBK dan ABK, nama siswa, dan data asesmen siswa ABK.

Sebelum melakukan pengumpulan data menggunakan instrumen angket. Instrumen yang telah disusun diuji cobakan 
terlebih dahulu kepada responden di luar sampel penelitian. Hal ini sesuai dengan pendapat Sugiyono (2017) mengatakan bahwa instrumen jumlah anggota sampel yang digunakan untuk pengujian instrumen sekitar 30 orang. Uji Coba Instrumen dilakukan di SDN Brebes 02 yang merupakan sekolah inklusi dengan responden sebanyak 33 siswa. maksud uji coba instrumen adalah untuk menguji validitas dan reliabilitas instrumen yang akan digunakan dalam penelitian. Instrumen yang diuji coba, dianalisis dengan tujuan untuk menyeleksi butir-butir yang valid, handal, dan komunikatif melalui teknik korelasi product moment antara skor masingmasing butir dengan skor total (Azwar, 2011). Hasil penghitungan uji validitas dapat dikatakan valid apabila nilai $r>r$ tabel. Sedangkan untuk uji reliabilitas dapat dikatakan reliabel jika nilai cronbach alpa $>0,6$ (Prayitno, 2010). Dari hasil pengujian validitas dan reliabilitas instrumen diperoleh beberapa butir yang koefisien validitasnya signifikan $(\alpha=0,05, \mathrm{r}>0,344)$. untuk variabel sekolah inklusi diperoleh 21 butir, dengan reliabilitas sebesar 0,791 variabel kepekaan sosial diperoleh 34 butir dengan reliabilitas sebesar 0,770 .

Selanjutnya dilakukan analisis data untuk mengetahui pengaruh antara variabel $\mathrm{X}$ dan Y. Dengan sekolah inklusi sebagai variabel $\mathrm{X}$ (variabel bebas) dan kepekaan sosial sebagai variabel Y (variabel terikat).
Teknik analisis data yang digunakan dalam penelitian ini adalah analisis deskriptif, uji prasyarat analisis, dan analisis regresi sederhana (Akdon \& Riduwan, 2013). Teknik analisis data dilakukan dengan bantuan software SPSS 21.0. Analisis deskriptif variabel sekolah inklusi dan kepekaan sosial dilakukan dengan analisis indeks. Analisis indeks digunakan untuk mengetahui persepsi umum responden mengenai sebuah variabel yang diteliti (Ferdinand, 2013: 292). Uji Prasyarat analisis terdiri dari uji normalitas dan uji reliabilititas. Uji normalitas bertujuan untuk memastikan bahwa data penelitian berdistribusi normal (berdistribusi secara merata). Sedangkan uji reliabilitas untuk menguji keajegan atau kekonsistenan data ketika dilakukan pengukuran yang berkali-kali. Analisis regresi sederhana digunakan untuk mengetahui arah hubungan dan pengaruh variabel sekolah inklusi terhadap variabel kepekaan sosial. Kriteria pengambilan keputusan dari hipotesis adalah apabila nilai $\mathrm{t}_{\text {hitung }} \leq \mathrm{t}_{\text {tabel}}$, maka $\mathrm{H}_{0}$ ditterima. Apabila $\mathrm{t}_{\text {hitung }}>\mathrm{t}_{\text {tabel }}$, maka $\mathrm{H}_{0}$ ditolak (Priyatno, 2010:59).

\section{HASIL DAN PEMBAHASAN \\ 3.1 Hasil}

Berdasarkan hasil analisis deskriptif dapat dilihat hasil nilai indeks sekolah dan kepekaan sosial sebagai berikut:

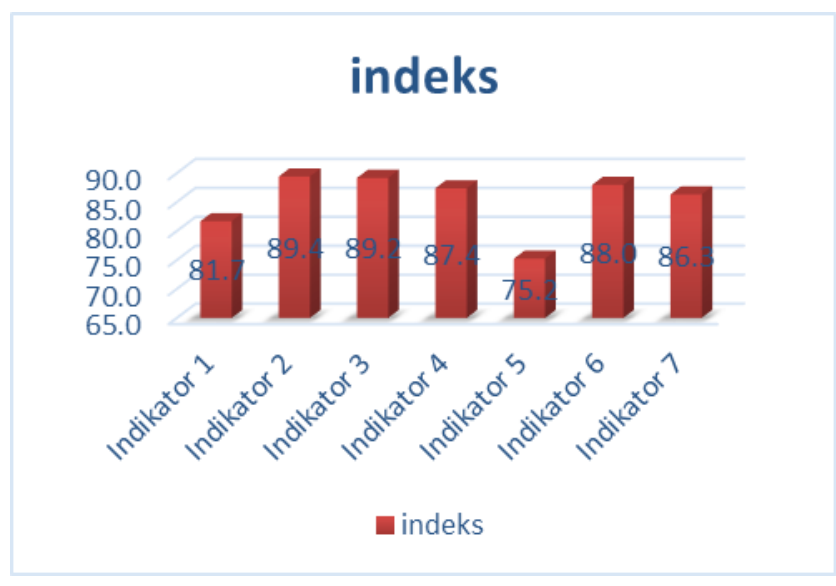

Gambar 1. Sekolah inklusi

Berdasarkan gambar 1 diketahui bahwa nilai indeks indikator 1 sebesar 81,7 $\%$, indikator 1 merupakan indikator Saling mendukung dan membantu untuk menciptakan lingkungan yang ramah. Indikator 2 sebesar $89,4 \%$ indikator 2 merupakan indikator 
memberikan kesempatan pada semua siswa untuk mengembangkan semua potensinya. Indikator 3 sebesar $89,2 \%$ indikator 3 merupakan indikator Meminimalisir diskriminasi. Indikator 4 sebesar 87,4\% indikator 4 merupakan indikator Kurikulum yang responsif terhadap peserta didik. Indikator 5 sebesar $75,2 \%$, indikator 5 merupakan indikator Pelajaran dapat diakses oleh semua peserta didik. Indikator 6 sebesar
$88,0 \%$, indikator 6 merupakan indikator Pembelajaran secara aktif mendorong pemahaman tentang perbedaan dan sekolah inklusi. Indikator 7 sebesar $86,3 \%$, indikator 7 merupakan indikator Semua peserta didik mendapatkan dukungan dan dorongan. Indikator 1,2 dan 3 masuk ke dalam dimensi budaya. Sedangkan indikator 4, 5,6, dan 7 masuk ke dalam dimensi praktik.

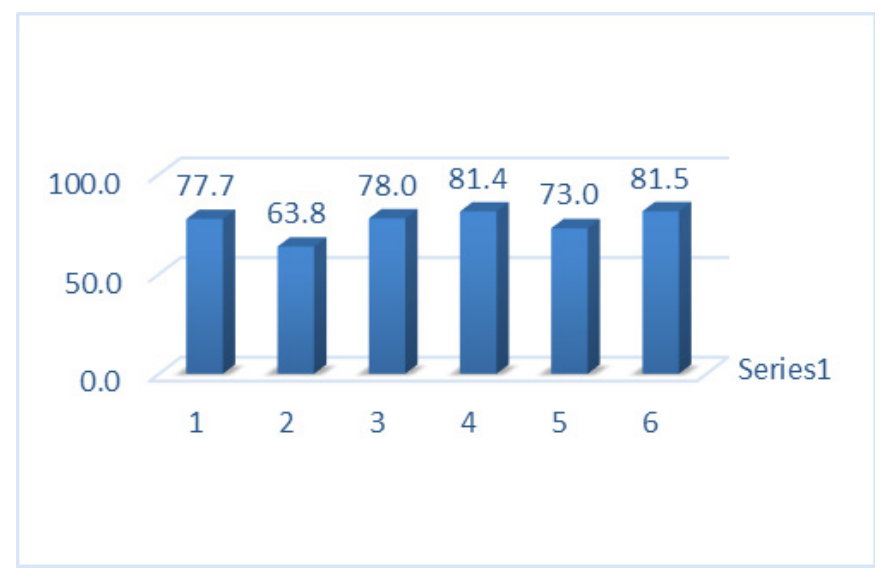

Gambar 2. Kepekaan Sosial

Berdasarkan gambar 2 diketahui bahwa nilai indeks indikator 1 sebesar 77,7\%, Indikator 1 merupakan indikator Memposisikan diri pada kondisi orang lain dan membantu menyelesaikan masalah. Indikator 2 sebesar $63,8 \%$, Indikator 2 merupakan indikator Kemampuan imajinatif. Indikator 3 sebesar $78,0 \%$, Indikator 3 merupakan indikator Kepedulian terhadap sesama. Indikator 4 sebesar 81,4\%, Indikator 4 merupakan indikator Saling menghargai antar teman. Indikator 5 sebesar $73,0 \%$, Indikator 5 merupakan indikator Memahami keadaan orang lain. Indikator 6 sebesar $81,5 \%$, indikator 6 merupakan indikator Mengalami perasaan emosional orang lain. Indikator 1 masuk dalam dimensi Perspective taking (Pengambilang Perspektif), Indikator 2 masuk dalam dimensi
Fantasy (Fantasi), Indikator 3,4,5, dan 6 masuk dalam dimensi Emphatic Concern (orientasi seseorang terhadap permasalahan orang lain meliputi perasaan peduli dan simpati).

Sebelum dilakukan analisis regresi sederhana dilakukan pengujian persyaratan analisis yang terdiri dari uji normalitas dan uji linieritas. Uji normalitas digunakan untuk membuktikan apakah data berdistibusi normal atau tidak dengan menggunakan Uji Liliefors. Uji Linieritas digunakan untuk mengetahui apakah data mempunyai hubungan linier dengan menggunakan test for linearity. Dengan menggunakan taraf signifikansi 0,05 dengan banyaknya $n=111$ didapat seperti tabel berikut.

Tabel 2. Uji Normalitas

\begin{tabular}{lrll}
\hline & \multicolumn{3}{c}{ Kolmogorov-Smirnov $^{\mathbf{a}}$} \\
\cline { 2 - 4 } & Statistic & Df & Sig. \\
\hline Sekolah inklusi &, 071 & 111 &, $200^{*}$ \\
\hline Kepekaan sosial &, 050 & 111 &, $200^{*}$ \\
\hline *. This is a lower bound of the true significance. \\
a. Lilliefors Significance Correction
\end{tabular}


Berdasarkan tabel 1 hasiluji normalitas diperoleh nilai signifikansi sekolah inklusi dan kepekaan sosial lebih besar dari 0,05
$(0,200>0,05)$. Dengan demikian, hasil pengujian diketahui bahwa data berdistribusi normal.

Tabel 3. Hasil Linieritas

\begin{tabular}{|c|c|c|c|c|c|c|c|}
\hline \multicolumn{8}{|c|}{ ANOVA Table } \\
\hline & & & $\begin{array}{l}\text { Sum of } \\
\text { Squares }\end{array}$ & Df & $\begin{array}{l}\text { Mean } \\
\text { Square }\end{array}$ & $\mathbf{F}$ & Sig. \\
\hline \multirow{5}{*}{$\begin{array}{l}\text { kepekaan sosial * } \\
\text { sekolah inklusi }\end{array}$} & \multirow{3}{*}{$\begin{array}{l}\text { Between } \\
\text { Groups }\end{array}$} & (Combined) & 5994,346 & 24 & 249,764 & 4,550 & 000 \\
\hline & & Linearity & 4018,230 & 1 & 4018,230 & 73,196 &, 000 \\
\hline & & Deviation from Linearity & 1976,116 & 23 & 85,918 & 1,565 & ,072 \\
\hline & \multicolumn{2}{|c|}{ Within Groups } & 4721,131 & 86 & 54,897 & & \\
\hline & \multicolumn{2}{|l|}{ Total } & 10715,477 & 110 & & & \\
\hline
\end{tabular}

Berdasarkan tabel 3 hasil uji lineritas kepekaan sosial dengan sekolah inklusi diperoleh nilai signifikansi sebesar 0,000 $(0,000<0,05)$ yang berarti data mempunyai hubungan yang linier. Berdasarkan hasil tersebut data telah memenuhi uji prasyarat analisis. Variabel sekolah dan kepekaan sosial diketahui data berdistribusi norma dan mempunyai hubungan yang linier. Selanjutnya, dilakukan pengujian dengan analisis regresi sederhana (tabel 4).

Tabel 4. Hasil Analisis Regresi Sederhana

\begin{tabular}{crrrr}
\multicolumn{5}{c}{ Model Summary } \\
\hline Model & R & R Square & $\begin{array}{c}\text { Adjusted R } \\
\text { Square }\end{array}$ & $\begin{array}{c}\text { Std. Error of the } \\
\text { Estimate }\end{array}$ \\
1 &, $612^{\text {a }}$ &, 375 &, 369 & 7,839 \\
\hline
\end{tabular}

a. Predictors: (Constant), sekolah inklusi

Tabel 5. Perhitungan Persamaan Regresi Sederhana

\begin{tabular}{|c|c|c|c|c|c|c|}
\hline \multirow{2}{*}{\multicolumn{2}{|c|}{ Model }} & \multicolumn{2}{|c|}{$\begin{array}{c}\text { Unstandardized } \\
\text { Coefficients }\end{array}$} & \multirow{2}{*}{$\begin{array}{c}\text { Standardized } \\
\text { Coefficients } \\
\text { Beta } \\
\end{array}$} & \multirow[t]{2}{*}{$\mathbf{T}$} & \multirow[t]{2}{*}{ Sig. } \\
\hline & & B & Std. Error & & & \\
\hline \multirow{2}{*}{1} & (Constant) & 27,349 & 9,493 & & 2,881 & ,005 \\
\hline & Sekolah inklusi & 1,064 &, 132 & ,612 & 8,087 &, 000 \\
\hline
\end{tabular}

a. Dependent Variable: kepekaan sosial

Dari data pada tabel 5 dengan taraf signifikansi 0,05 dan $\mathrm{t}_{\text {tabel }} 1,982$ diketahui hasil $\mathrm{t}_{\text {titung }}$ sebesar 1,982. Oleh karena $\mathrm{t}_{\text {hitung }}$ $>t_{\text {tabel }}(8,087>1,982)$, dapat disimpulkan bahwa terdapat pengaruh yang signifikan sekolah inklusi terhadap kepekaan sosial anak SD Slerok 2 Kota Tegal. Berikut ini adalah persamaan regresi linear sederhana:

$$
\mathrm{Y}=27,349+1,064 \mathrm{X}
$$

Keterangan:

$\mathrm{Y}=$ Kepekaan Sosial

$\mathrm{a}=$ Konstanta

$\mathrm{b}=$ Koefisien regresi

$\mathrm{X}=$ Sekolah Inklusi.
Berdasarkan persamaan regresi linier sederhana tersebut, diketahui bahwa sekolah inklusi merupakan variabel independen (X), sedangkan kepekaan sosial merupakan variabel dependen (Y). Adapun nilai kontanta dan koefisien regresi variabel $\mathrm{X}$ masingmasing sebesar 27,349 dan 1,064. Konstanta 27,349 yang artinya jika nilai sekolah inklusi 0, maka nilai kepekaan sosialnya sebesar 27,349. Koefisien regresi variabel sekolah inklusi sebesar 1,064. Artinya jika nilai sekolah inklusi mengalami kenaikan 1 , maka kepekaan sosial anak akan mengalami peningkatan sebesar 1,064. Koefisien bernilai positif menunjukkan bahwa terdapat 
hubungan yang positif antara sekolah inklusi dan kepekaan sosial anak.

Dari Tabel 3, diketahui nilai R sebesar

0,612. Dan dapat diketahui bahwa variabel sekolah inklusi dengan kepekaan sosial mempunyai korelasi yang kuat. Analisis koefisien determinasi diperoleh hasil pada $\mathrm{R}$ Square sebesar 0,375. Hal ini menunjukkan bahwa persentase sumbangan variabel sekolah inklusi terhadap kepekaan sosial sebesar $37,5 \%$. Jadi besarnya pengaruh sekolah inklusi terhadap kepekaan sosial yaitu $37,5 \%$, sedangkan sisanya $62,5 \%$ dipengaruhi oleh faktor-faktor lain yang tidak diteliti dalam penelitian ini.

\subsection{Pembahasan}

Berdasarkan hasil analisis deskriptif diketahui bahwa nilai indeks sekolah inklusi sebesar 85,3\% (kategori tinggi). Hal ini berarti persepsi responden terhadap itemitem pernyataan pada variabel sekolah inklusi tinggi. Dimensi yang paling dominan pada variabel sekolah inklusi adalah "dimensi budaya" dengan nilai indeks sebesar 85,9\% yang meliputi indikator saling mendukung dan membantu untuk menciptakan lingkungan yang ramah, memberikan kesempatan pada semua siswa untuk mengembangkan semua potensinya, dan meminimalisir diskriminasi. Dimensi budaya adalah tentang menciptakan sebuah jaminan, penerimaan, kolaborasi, stimulasi komunitas, dimana setiap orang merasa dihargai. Nilai-nilai inklusif diberikan dan disampaikan kepada semua pelakasana, anak-anak, pemerintah, sekolah, orang tua atau wali. Adapun presentase indikator yang paling dominan pada sekolah inklusi adalah indikator " memberikan kesempatan kepada semua siswa untuk mengembangkan semua potensinya" yaitu sebesar $89,4 \%$ dan "meminimalisir diskriminasi" yaitu sebesar $89,2 \%$. Indikator memberikan kesempatan kepada semua siswa untuk mengembangkan semua potensinya memiliki indeks yang besar karena sekolah berusaha memberikan pelayanan pada semua siswa baik siswa ABK maupun ATBK untuk mendapatkan pendidikan yang baik. sebagai sekolah inklusi SD Slerok 2 Kota Tegal menerima semua siswa baik siswa ABK maupun
ATBK. Siswa ABK diterima melalui hasil asesmen sehingga sekolah mengetahui siswa ABK yang perlu diberikan layanan khusus. Indikator meminimalisir diskriminasi juga memiliki nilai indeks yang cukup besar. Hal ini karena sekolah sudah menanamkan sikap menghargai dan toleransi antar teman kepada siswa. keberagaman dan keterbatasan siswa dijadikan sebagai pembelajaran untuk saling menghargai dan saling menghormati antar sesama. Guru juga memberikan perlakuan yang sama kepada semua siswa tanpa membedakan anak tersebut normal atau berkebutuhan khusus. Guru berusaha untuk menciptakan lingkungan yang mengakomodasi semua siswa sehingga siswa merasa hangat dan nyaman tanpa merasa didiskriminasi. Sejalan dengan hal tersebut, Permendiknas No 70 Tahun 2009 Tentang Pendidikan InklusifPasal 2 ayat 2 menyatakan bahwa sekolah inklusif bertujuan untuk mewujudkan penyelenggaraan pendidikan yang menghargai keanekaragaman dan tidak diskriminatif bagi peserta didik.

Sedangkan indikator yang memiliki presentase paling rendah adalah indikator "Pelajaran dapat diakses oleh semua peserta didik" dengan nilai indeks sebesar 75,2 $\%$. Hal ini karena pembelajaran dalam kelas inklusif memiliki banyak tantangan dan hambatan. Sehingga mengakibatkan perhatian guru terpecah kepada siswa ABK dan ATBK. Hal ini sejalan dengan pendapat Smith (2017:404) bahwa guru disekolah inklusi tidak yakin tentang cara membuat perubahan materi, metode dan harapannya untuk dapat memberikan pengajaran yang layak kepada siswa dengan kebutuhan yang berbeda. Berdasarkan hasil wawancara guru di SD Slerok 2 Kota Tegal kesulitan untuk memberikan pembelajaran yang dapat dipahami oleh seluruh siswa. Tidak adanya guru GPK dan pelatihan terhadap guru tentang pelaksanaan pendidikan inklusif membuat guru kurang dapat memahami kebutuhan ABK. Keterbatasan pengetahuan yang dimiliki guru untuk melaksanakan pembelajaran di sekolah inklusi menyebabkan kesulitan dalam menentukan metode dan model pembelajaran yang tepat, guru juga 
kesulitan untuk dapat mengakomodasi semua kebutuhan siswa baik siswa berkebutuhan khusus maupun siswa tanpa kebutuhan khusus. Beban guru di sekolah inklusi pun akhirnya menjadi lebih besar jika dibandingkan beban guru di sekolah biasa. Selain itu dalam beberapa tahun ini dana untuk pelaksanaan pendidikan inklusi yang seharusnya diberikan pemerintah ke SD Slerok 2 Kota Tegal sudah tidak berjalan lagi. Sekolah sudah tidak menerima dana lagi, disisi lain untuk menyelenggarakan sekolah inklusi yang dapat mengakomodasi semua kebutuhan peserta didik dibutuhkan dana yang cukup besar. Oleh karena itu seperti hasil penelitian siswa pun menjadi kesulitan dalam menerima pembelajaran.

Analisis deskriptif terhadap kepekaan sosial anak diketahui hasil penghitungan nilai indeks kepekaan sosial sebesar $75,9 \%$ (kategori tinggi). Hal ini berarti persepsi responden terhadap item-item pernyataan pada variabel kepekaan sosial tinggi. Indikator yang paling tinggi adalah "mengalami perasaan emosional orang lain" sebesar 81,5\% . Hal ini sesuai dengan pendapat (Kartadinata, 2007) dalam Riza, dkk (2014:30) mengungkapkan bahwa kematangan emosi anak sekolah dasar meliputi mengenali perasaan diri sendiri dan orang lain, memahami perasaan-perasan diri dan orang lain, dan mengekspresikan perasaan secara wajar. Anak-anak di SD Slerok 2 Kota Tegal memiliki kepedulian terhadap sesama, dan membantu temannya jika mengalami kesulitan dan mampu memahami perasaan yang dialami oleh temannya. Kustawan (2016:18) mengemukakan bahwa peserta didik normal dapat belajar keterbatasan, kelebihan, serta tertentu pada teman-temannya. Sehingga melalui sekolah inklusi siswa akan tumbuh rasa kepedulian terhadap teman-temannya, mengembangkan keterampilan sosial, berempati terhadap permasahalan, dan membantu siswa berkebutuhan khusus dan teman-teman siswa pada umumnya yang mendapat kesulitan. Sedangkan indikator yang paling rendah adalah "Kemampuan imajinatif" yaitu sebesar $63,8 \%$. Hal ini sesuai dengan pendapat Piaget bahwa anak pada usia sekolah dasar berada pada tahap operasional kongkret dimana anak mampu mengoperasikan berbagai logika namun masih dalam benda kongkret dan anak belum bisa memecahkan masalah secara abstrak. Maka tingkat imajinatif pada anak usia ini masih kurang karena mereka perlu sesuatu hal yang kongkret.

Banyak faktor yang mempengaruhi pembentukan kepekaan sosial anak. Dari banyak faktor tersebut sekolah inklusi merupakan salah satu faktor yang cukup besar mempengaruhi kepekaan sosial anak. Kepekaan sosial muncul dan berkembang melalui pengalaman. Pengalaman belajar individu pada hakikatnya merupakan hasil dari interaksi antara pribadi individu dengan lingkunggannya. Lingkungan peserta didik dan orang-orang yang berada di sekitarnya sangat berpengaruh besar terhadap kepekaan sosial anak karena sikap sosial anak akan berkembang melalui pengalaman di lingkungan sekitarnya. Anak yang sering terlibat dalam interaksi sosial akan cenderung lebih peka terhadap lingkungannya dari pada anak yang kurang terlibat dalam lingkungannya. anak yang kurang beriteraksi sosial akan mengakibatkan anak menjadi pribadi yang individualis. Lingkungan sekolah inklusi dan nilai-nilai yang terkandung di dalamnya syang dapat mengembangkan kepekaan sosial anak.

Temuan penelitian menunjukkan bahwa sekolah inklusi berpengaruh positif dan signifikan terhadap kepekaan sosial. Besar sumbangan pengaruh sekolah inklusi terhadap kepekaan sosial adalah 37,5\%, sedangkan sisanya dipengaruhi oleh faktor-faktor lainnya yang tidak diteliti dalam penelitian ini. Hal ini berarti keberadaan sekolah inklusi memiliki pengaruh terhadap tingkat kepekaan sosial anak SD Slerok 2 Kota Tegal, artinya apabila nilai-nilai inklusi di sekolah inklusi tinggi maka tingkat kepekaan sosial anak akan tinggi pula. Namun sebaliknya jika nilai inklusi sekolah rendah maka tingkat kepekaan sosial siswa akan rendah. Sehingga dapat disimpulkan bahwa adanya sekolah inklusi dapat meningkatkan kepekaan sosial 
anak. Agar kepekaan sosial anak meningkat maka nilai sekolah inklusi harus ditingkatkan. Sekolah inklusi dapat tercipta dengan baik apabila sekolah dapat membangun lingkungan yang inklusif dengan baik. Sekolah harus dapat menciptakan lingkungan yang ramah dan responsif terhadap segala sesuatu. Kondisi yang seperti ini akan membentuk kepekaan sosial siswa yang baik.

Siswa-siswa berkebutuhan khusus dapat menjadi aset-aset pribadi dan sosial bagi kelas inklusif yang akan meningkatkan kualitas lingkungan pembelajaran. Wolfensberg (Smith, 2017: 121) orang penyandang terbelakang mental (siswa berkebutuhan khusus) akan membawa pada hubungan orang lain yaitu: spontifitas yang wajar dan positif; kecenderungan untuk merespon orang lain dengan baik dan hangat; kecenderungan merespon orang lain dengan jujur; kecenderungan untuk mempercayai orang. Dengan demikian sekolah inklusi dapat mengembangkan hubungan sosial ke arah yang lebih positif.

Berdasarkan hasil wawancara dengan wali kelas dan kepala sekolah diketahui bahwa anak-anak di SD Slerok 2 Kota Tegal memiliki kelebihan dalam hal kepedulian terhadap lingkungan sekitarnya. Anak-anak cenderung memiliki kepekaan sosial yang tinggi, senang untuk membantu dan menolong teman yang mengalami kesulitan. Saling menghargai dan tidak membeda-bedakan satu dengan lainnya. Anak-anak berkebutuhan khusus dan normal dapat berinteraksi dan bekerja sama dengan baik. Anak- anak telah diberikan pemahaman terkait anak yang berkebutuhan khusus sehingga anakanak dapat memahami kekurangan temannya dan tidak melakukan diskriminasi.

Pada usia sekolah dasar perkembangan sosial anak berada pada masa yang rentan. Siswa sekolah cenderung senang bermain, senang bekerjasama, membangkang, dan meniru apa yang anak lihat di lingkungan sekitarnya. Siswa perlu mendapatkan bimbingan agar memiliki sikap sosial yang baik demi masa depannya. Kepekaan sosial anak perlu dibangun sejak dini. Tidak hanya sekolah tetapi semua pihak perlu bekerjasama untuk meningkatkan kepekaan sosial anak. Sekolah inklusi sebagai sekolah yang ramah untuk semua perlu dukungan dan kerjasama dari berbagai pihak. Sekolah tidak dapat berdiri sendiri dalam praktek penyelenggaraan sekolah inklusi. Perlu kerjasama dari pemerintah dan orang tua agar pendidikan inklusif bagi siswa dapat terlaksana dengan baik.

\section{KESIMPULAN}

Berdasarkan hasil penelitian dan pembahasan, maka penelitian ini dapat disimpulkan bahwa sekolah inklusi berpengaruh positif dan signifikan sebesar 37,5\% terhadap kepekaan sosial anak SD Slerok 2 Kota Tegal. Hal ini berarti keberadaan sekolah inklusi memiliki pengaruh terhadap tingkat kepekaan sosial anak, artinya apabila nilai-nilai inklusi di sekolah inklusi tinggi maka tingkat kepekaan sosial anak akan tinggi pula. Namun sebaliknya jika nilai inklusi sekolah rendah maka tingkat kepekaan sosial siswa akan rendah. Sehingga dapat disimpulkan bahwa adanya sekolah inklusi akan meningkatkan kepekaan sosial anak.

Penyelenggaraan sekolah inklusi seharusnya lebih disiapkan dalam segala aspek, serta masyarakat perlu diberikan gambaran terkait sekolah inklusi. Agar masyarakat tidak ragu untuk memasukkan anaknya ke sekolah inklusi. Guru harus dapat menanamkan kepekaan sosial sejak dini kepada para siswa. siswa sejak awal perlu ditanamkan nilai-nilai sosial, kepedulian, sikap saling menghargai, menghormati, dan toleransi. Sekolah juga harus mewujudkan lingkungan yang kondusif agar dapat mengembangkan sikap kepekaan sosial anak. sehingga dewasa nanti dapat menjadi pribadi yang peduli dengan lingkungan sekitar.

\section{DAFTAR PUSTAKA}

Akdon., \& Riduwan. (2013). Rumusan dan Data Dalam Analisis Statistika. Bandung. Alfabeta

Azwar, S. (2011). Reliabilitas dan Validitas. Yogyakarta: Pustaka Pelajar

Booth, T., \& Ainscow, M. (2002.) Index For Inclusion, developing learning and participations in schools. CSIE

Dewi, N. K. (2017). Manfaat Program Pendidikan Inklusif untuk AUD. Jurnal Pendidikan Anak. 6(1): 13

Ferdinand, A. (2013). Metode Penelitian Manajemen. Semarang. Badan Penerbit Universitas Diponegoro 
Kustawan. (2016). Manajemen Pendidikan Inklusif. Depok: Luxima.

Priyatno, D. (2010). Teknik Mudah dan Cepat Melakukan Analisis Data Penelitian dengan SPSS dan Tanya Jawab Ujian Pendadaran. Yogyakarta. Gaya Media.

Rohima, E. (2018). Upaya Meningkatkan Kepekaan Sosial Melalui Layanan Bimbingan di MAN Pematang Bandar. Skripsi. Medan: Universitas Islam Negeri Sumatra Utara.

Sarwono., \& Meinarno. (2009). Psikologi Sosial. Jakarta: Salemba Humanika.

Smith. (2018). Sekolah Untuk Semua Teori dan Implementasi Inklusi. Bandung: Penerbit Nuansa Cendikia.

Sugiyono. (2017). Metode Penelitian Kombinasi. Bandung: Alfabeta. 